\title{
Pembelian Impulsif pada Remaja Akhir Ditinjau dari Kontrol Diri
}

\author{
Ardian Rahman Afandi ${ }^{1} \mathcal{E}$ Sri Hartati ${ }^{2}$ \\ Fakultas Psikologi Universitas Gadjah Mada
}

\begin{abstract}
This study aims to examine the role of self-control on impulsive buying among late adolescence. The hypothesis of this study is that self-control has a role on impulsive buying. Five hundred and nine subjects consisted of freshmen from 18 faculties and 1 vocational school participated in this study. Measuring instruments used in this study were adapted from an impulsive buying scale and a self-control scale. The results of this study can be concluded that self-control has a role on impulsive buying among late adolescence. Additional analysis indicates that there were differences in impulsive buying rates in gender group and the amount of money that they received monthly from parents, while the difference in self-control rates was shown in the cluster group.
\end{abstract}

Keywords: impulsive buying; late adolescence; self-control

Abstrak. Penelitian ini bertujuan untuk mengetahui peran kontrol diri terhadap pembelian impulsif pada remaja akhir. Hipotesis penelitian ini adalah kontrol diri memiliki peran terhadap pembelian impulsif. Subjek dalam penelitian ini berjumlah 509 subjek yang terdiri dari mahasiswa tingkat awal di Universitas $X$ yang berasal dari 18 fakultas dan 1 sekolah vokasi. Alat ukur yang digunakan dalam penelitian ini merupakan adaptasi skala pembelian impulsif dan adaptasi dari skala kontrol diri. Hasil regresi linier sederhana menunjukkan hasil $\mathrm{R}^{2}=0,285(\mathrm{p}<0,01)$. Hal ini menunjukkan bahwa kontrol diri memiliki sumbangan efektif terhadap pembelian impulsif pada remaja akhir sebesar 28,5\%. Analisis tambahan dilakukan dalam penelitian ini dengan membandingkan demografis remaja akhir. Analisis tambahan menunjukkan terdapat perbedaan tingkat pembelian impulsif pada kelompok jenis kelamin dan kepemilikan jumlah uang saku, sedangkan perbedaan tingkat kontrol diri ditunjukkan pada kelompok klaster fakultas.

Keywords: kontrol diri; pembelian impulsif; remaja akhir

Kegiatan berbelanja semakin mudah dilakukan dengan banyaknya tempat yang menjual sebuah produk. Hal ini dapat mengakibatkan peningkatan perilaku konsumtif. Menurut Kasumaningrum (2015), masyarakat Indonesia memiliki tingkat Marginal Propensity to Save (MPS) yang menurun dan Marginal Propensity to Consumption (MPC) yang semakin meningkat selama tiga tahun ini. Presentase

\footnotetext{
${ }^{1}$ Korespondensi mengenai isi artikel ini dapat dilakukan melalui ardianrahmana22@gmail.com

2 Atau melalui tatiet@ugm.ac.id

pengeluaran rata-rata per kapita dalam satu bulan pada tahun 2011 hingga 2014 menunjukkan peningkatan transaksi belanja setiap semesternya. Hasil riset yang dilakukan oleh MasterCard Asia Pasifik pada tahun 2015 (Primadhyta, 2015) menunjukkan bahwa $47 \%$ responden yang memiliki usia produktif (18-29 tahun) berniat membeli barang mewah pada tahun 2016. Dalam riset ini juga menunjukkan $26 \%$ dari $50 \%$ responden yang berasal dari Indonesia melakukan pembelian secara impulsif. 
Remaja Indonesia juga tidak luput dari perilaku pembelian impulsif. Menurut Muratore (2016) remaja yang melakukan pembelian secara impulsif cenderung untuk memiliki sensitivitas terhadap prestis, skema kualitas harga, kepekaan terhadap harga, kerawanan terhadap potongan harga, dan kesadaran diri terhadap nilai dibandingkan remaja yang tidak melakukan pembelian secara impulsif. Hal ini ditunjukkan dengan data wawancara pada tanggal 21 Mei 2017 kepada salah satu mahasiswa Fakultas Psikologi Universitas Gadjah Mada angkatan 2016 berinisial X yang menyebutkan bahwa terdapat kecenderungan perilaku yang mencari potongan harga.

Berdasarkan data wawancara, mahasiswa tingkat awal juga lebih cenderung melakukan pembelian secara impulsif bersama kelompoknya. Hal ini senada dengan penelitian terdahulu yang dilakukan oleh Silvera, Lavack, dan Kropp (2008) yang menyebutkan bahwa temanteman atau lingkungan sosial memberikan pengaruh kepada pembelian impulsif. Lingkungan pertemanan mahasiswa memberikan pengaruh yang besar terhadap pembelian impulsif. Ditambah lagi dengan penelitian yang dilakukan oleh Lee dan Kacen (2008) yang menyebutkan konsumen yang negara atau wilayahnya memiliki budaya kolektif cenderung akan menikmati perilaku pembelian impulsifnya.

Mahasiswa tingkat awal memiliki rata-rata usia 17-20 dan sedang memasuki masa remaja akhir yang menuju dewasa awal. Pada masa transisi tersebut, remaja mengalami perkembangan fisik, sosial, dan kognitif yang berproses secara bersama (Santrock, 2012). Hurlock (1997) menambahkan masa awal perkuliahan merupakan masa-masa penyesuaian diri terhadap lingkungan. Pada masa awal perkuliahan ini, mahasiswa masih melakukan penyesuaian diri, termasuk penyesuaian perilakunya.

Kecenderungan mahasiswa tingkat awal untuk melakukan kegiatan bersama teman-teman cukup tinggi termasuk melakukan pembelian. Hal ini ditunjukkan melalui observasi yang dilakukan pada penelitian ini, terlihat mahasiswa tingkat awal melakukan pembelian bersama teman-temannya lalu tidak menghabiskan makanan dengan jumlah yang banyak. Hal ini dapat dijelaskan melalui penelitian yang dilakukan Asch (1955) yang menyebutkan bahwa seseorang cenderung akan melakukan perilaku yang sama dengan kelompoknya bila sedang mengalami kebingungan. Hal ini menjadi salah satu faktor yang menambah kecenderungan mahasiswa tingkat awal melakukan pembelian secara impulsif.

Pembelian impulsif merupakan perilaku pembelian yang disebabkan oleh adanya dorongan yang sangat kuat, tiba-tiba, dan terus-menerus yang berupaya mendorong konsumen untuk membeli suatu benda (Rook, 1987). Pembelian impulsif dipengaruhi oleh dua faktor, yaitu faktor internal dan faktor eksternal. Faktor yang memengaruhi pembelian impulsif secara eksternal yaitu karakteristik toko (Engel, et al., 1973), kepemilikan uang, waktu, dan physical effort (Stern, 1962). Faktor internal yang memengaruhi pembelian impulsif yaitu karakteristik pembeli (Engel, et al., 1973), mental effort (Stern, 1962), dan kontrol diri (Roberts dan Manolis, 2012).

Hasil penelitian yang dilakukan oleh Roberts dan Manolis (2012) menyebutkan bahwa kontrol diri memiliki hubungan yang negatif dengan pembelian impulsif. Semakin tinggi kemampuan kontrol diri seseorang maka semakin rendah kecenderungan pembelian secara impulsif. Kontrol diri merupakan faktor yang penting untuk menahan pembelian impulsif. 
Menurut Sultan, et al. (2012), kontrol diri dapat menahan keinginan dan hasrat seseorang dalam melakukan perilaku. Lebih lanjut, Gailliot, et al. (2007) menyebutkan kontrol diri dapat mengendalikan pikiran, emosi, dorongan, dan perilaku manusia.

Lemahnya kontrol diri seseorang dapat diakibatkan oleh keadaan egodepleted yang merupakan sebuah kondisi dimana seseorang mengalami kelelahan dan penipisan kemampuan kontrol diri sehingga tidak bisa melakukan kontrol diri kembali (Baumesiter, et al., 2008). Kontrol diri yang lemah juga akan menyebabkan seseorang mudah terpersuasi oleh stimulus (Burkley, 2008). Pentingnya kontrol diri menahan keinginan seseorang dalam berperilaku menjadi salah satu alasan untuk melakukan penelitian ini.

Mahasiswa tingkat awal yang sedang memasuki masa remaja akhir sebaiknya berhemat dan tidak melakukan pemborosan. Kepemilikan uang yang masih berasal dari orangtua sebaiknya disimpan untuk keperluan yang akan datang. Namun pada kenyataannya, melalui wawancara kepada mahasiswa tingkat awal subjek X dan Y mengaku melakukan pembelian impulsif dan mengalami penyesalan dikemudian hari. Hal ini senada dengan penelitian yang dilakukan oleh Rook dan Hoch (1985) yang menyebutkan bahwa pembelian impulsif dapat memberikan rasa sesal pasca pembelian, berkurangnya keuangan pribadi, kepuasan pasca pembelian, serta dapat memengaruhi self-esteem. Kontrol diri memiliki peran yang penting untuk menghindari terjadinya pembelian impul-sif yang dapat memberikan dampak di kemudian hari.

Penelitian mengenai pembelian impulsif dan kontrol diri telah beberapa kali dilakukan, akan tetapi belum terdapat penelitian yang menyebutkan seberapa besar peran kontrol diri terhadap pembe- lian impulsif, faktor demografis yang dapat memengaruhi, jumlah subjek yang dapat diandalkan, serta subjek remaja dengan rentang usia yang sama namun heterogen. Penelitian mengenai kontrol diri dan pembelian impulsif ini diharapkan dapat memberikan manfaat kepada mahasiswa dalam menghindari pembelian impulsif. Hal ini menjadi salah satu alasan penelitian ini menarik untuk dilakukan secara mendalam kepada mahasiswa tingkat awal yang termasuk ke dalam rentang usia remaja akhir. Tujuan dalam penelitian ini adalah untuk mengetahui peran kontrol diri terhadap pembelian impulsif pada remaja akhir. Semakin tinggi kemampuan kontrol diri maka semakin rendah kecenderungan pembelian impulsif. Semakin rendah kemampuan kontrol diri, maka semakin tinggi kecenderungan pembelian impulsif. Hipotesis dalam penelitian ini adalah terdapat peran kontrol diri terhadap pembelian impulsif pada remaja akhir.

\section{Metode}

Subjek dalam penelitian ini adalah mahasiswa tingkat awal S1 dan D3 Universitas Gadjah Mada angkatan 2016 berjumlah 509 orang yang berasal dari 18 fakultas dan 1 sekolah vokasi yang dikelompokkan menjadi 5 klaster asal fakultas. Subjek lakilaki berjumlah 164 orang dan perempuan berjumlah 345 orang.

Kontrol diri menjadi variabel bebas dan pembelian impulsif menjadi variabel tergantung. Metode pengumpulan data yang digunakan pada penelitian ini adalah metode kuantitatif. Alat ukur yang digunakan pada penelitian ini menggunakan skala pembelian impulsif yang diciptakan oleh Verplanken dan Herabadi (2001) dan skala kontrol diri yang diciptakan oleh Tangney, Baumeister, dan Boone (2004). Kedua skala diadaptasi dan memiliki 
reliabilitas sebesar 0,854 untuk skala pembelian impulsif dan 0,869 untuk skala kontrol diri. Sebelum proses uji coba skala, aitem di dalam skala divalidasi melalui proses professional judgement dengan Dosen Pembimbing Skripsi. Uji coba dilakukan di Fakultas Psikologi UGM dengan subjek yang berjumlah 81 orang. Skala pembelian impulsif memiliki 20 aitem dan koefisien reliabilitas sebesar 0,854 . Skala kontrol diri memiliki 36 aitem dan koefisien reliabilitas sebesar 0,869 .

Pengambilan data dilakukan melalui google form online dengan menambahkan fitur single sign-in. Fitur tersebut akan menutup kemungkinan pemilik akun google mengisi lebih dari sekali. Metode analisis yang digunakan pada penelitian ini adalah analisis regresi linier sederhana.

\section{Hasil}

Penelitian ini memiliki hipotesis terdapat peran kontrol diri terhadap pembelian impulsif. Kategorisasi skor pembelian impulsif dalam penelitian ini mengungkapkan terdapat 5,7\% kecenderungan yang tinggi dalam pembelian impulsif, $39,3 \%$ termasuk ke dalam kategori sedang, $49,9 \%$ termasuk ke dalam kategori rendah, dan 5,1\% termasuk ke dalam kategori sangat rendah. Lalu, kategorisasi skor kontrol diri dalam penelitian ini mengungkapkan terdapat 2,9\% kecenderungan yang rendah, $62,3 \%$ termasuk ke dalam kategori sedang, dan 34,8\% termasuk ke dalam kategori tinggi.

Penelitian ini juga telah dilakukan uji asumsi, yang terdiri dari uji normalitas dan uji linieritas. Berdasarkan uji normalitas dan uji linieritas, diketahui bahwa sebaran data dapat dikatakan normal dan linier. Hal ini dapat dilihat melalui nilai KSZ sebesar 1.356 untuk pembelian impulsif dan 1,107 untuk kontrol diri yang berarti sebaran data pada penelitian ini normal.
Hasil uji linieritas menunjukkan terdapat hubungan yang linier antara variabel kontrol diri dengan pembelian impulsif terlihat nilai signifikansi linieritas 0,000 $(p<0,05)$ dan deviation from linearity 0,744 $(p>0,05)$.

Hasil uji hipotesis yang dilakukan menggunakan analisis regresi linier sederhana menunjukkan bahwa kontrol diri memiliki peran terhadap pembelian impulsif secara signifikan. Hal ini ditunjukkan dengan nilai $F$ sebesar 201,704 dan $p<0,001$. Sumbangan efektif yang dapat diketahui melalui koefisien determinan $\left(\mathrm{R}^{2}\right)$ mendapatkan skor 0,285 . Hal ini menunjukkan terdapat $28,5 \%$ peran kontrol diri terhadap pembelian impulsif serta masih terdapat $71,5 \%$ peran variabel lain. Persamaan regresi untuk regresi linier sederhana menunjukkan arah yang negatif. Hal ini didapatkan melalui koefisien regresi kontrol diri sebesar -0,383. Hasil tersebut menunjukkan bahwa setiap peningkatan kontrol diri sebesar $1 \%$ maka pembelian impulsif akan menurun sebesar $0,383 \%$.

Hasil analisis tambahan menggunakan t-test menunjukkan terdapat perbedaan yang signifikan berdasarkan jenis kelamin pada pembelian impulsif $(p=0,006)$. Hasil analisis tambahan menggunakan one-way anova menunjukkan terdapat perbedaan yang signifikan berdasarkan kepemilikan uang saku pada pembelian impulsif $(p=0,009)$ dan berdasarkan klaster fakultas pada kontrol diri $(\mathrm{p}=0,017)$. Analisis tambahan pembelian impulsif berdasarkan asal daerah dan klaster fakultas tidak menunjukkan perbedaan yang signifikan, sedangkan analisis tambahan kontrol diri berdasarkan jenis kelamin, asal daerah, dan kepemilikan uang saku tidak menunjukkan perbedaan yang signifikan. 


\section{Diskusi}

Penelitian ini bertujuan untuk mengetahui seberapa besar peran kontrol diri terhadap pembelian impulsif pada remaja akhir. Hasil analisis regresi linier sederhana menunjukkan bahwa hipotesis dalam penelitian ini diterima, yaitu terdapat peran yang signifikan antara kontrol diri terhadap pembelian impulsif. Hal ini senada dengan penelitian yang dilakukan oleh Roberts dan Manolis (2012) yang menyebutkan bahwa kontrol diri merupakan salah satu faktor yang memengaruhi pembelian impulsif. Semakin tinggi kemampuan kontrol diri seseorang maka semakin rendah kecenderungan seseorang untuk melakukan pembelian impulsif, dan semakin rendah kemampuan kontrol diri seseorang maka kecenderungan pembelian impulsifnya semakin tinggi. Hal ini juga disebutkan oleh Baumeister, et al. (2008) bahwa konsumen akan lebih tidak berpikir ketika membeli dan memanjakan dirinya ketika mengalami ego-depletion. $\mathrm{R}^{2}$ menunjukkan sumbangan efektif kontrol diri sebesar $28,5 \%$ terhadap pembelian impulsif, sehingga masih terdapat $71,5 \%$ variabel lain yang menyumbangkan perannya. Senada dengan Engel, et al. (1973) yang menyebutkan terdapat faktor karakteristik toko dan Stern (1962) yang menyebutkan uang, waktu, dan physical effort menjadi salah satu pengaruh pembelian impulsif.

Melemahnya kontrol diri juga dapat mengakibatkan seseorang mudah untuk terpersuasi. Burkley (2008) menyebutkan bahwa kontrol diri memiliki peran untuk mempertahankan dari segala bentuk persuasi. Persuasi dalam perilaku konsumen dapat dicontohkan persuasi toko, persuasi bentuk, persuasi iklan, persuasi teman, atau keinginan dari dalam diri untuk membeli. Hasil analisis membuktikan bahwa pentingnya kontrol diri dalam mena- han diri dari persuasi pembelian, termasuk pembelian secara impulsif. Loudon dan Bitta (1984) menyebutkan terdapat pengaruh toko yang mengakibatkan perilaku impulsif, yaitu ukuran toko, jumlah produk, major shopping trips, frequenxy of product purchase, absence of shopping list dan number of years married. Hal ini dapat dihindari melalui kemampuan kontrol diri yang kuat agar tidak mudah terpersuasi.

Uji analisis tambahan menunjukkan terdapat perbedaan kecenderungan pembelian impulsif pada jenis kelamin lakilaki dan perempuan. Berdasarkan hasil analisis, subjek perempuan lebih tinggi kecenderungan pembelian impulsifnya dibandingkan dengan subjek laki-laki. Hal ini senada dengan penelitian yang dilakukan Coley dan Burgees (2003) serta Muratore (2016) yang menyebutkan bahwa wanita memiliki kecenderungan yang lebih tinggi dalam melakukan pembelian secara impulsif. Hal ini didasari oleh emosi dalam pembelian, mood management, dan ketahanan dalam melakukan pembelian yang dilakukan wanita lebih besar dan lebih positif daripada pria.

Perbedaan kepemilikan uang saku juga menunjukkan terdapat perbedaan yang signifikan. Berdasarkan hasil analisis, subjek yang mendapatkan uang saku $<$ Rp500.000 memiliki kecenderungan yang lebih rendah pembelian impulsifnya dibandingkan kategori uang saku yang lain. Hal ini senaada dengan pernyataan yang dikemukakan oleh Stern (1962) bahwa kepemilikan uang memiliki peran terhadap pembelian impulsif.

Hasil analisis menyebutkan tidak terdapat perbedaan yang signifikan antara pembelian impulsif bila dibandingkan dengan asal daerah dan klaster fakultas. Hal ini dapat disebabkan oleh budaya timur yang dapat dikatakan relatif sama. Hal ini mendukung pendapat yang dikemukakan oleh Lee dan Kacen (2008) yang menye- 
butkan bahwa budaya kolektif lebih menikmati pembelian impulsif. Hasil analisis juga tidak menunjukkan perbedaan yang signifikan dalam kemampuan kontrol diri bila dibandingkan dengan jenis kelamin laki-laki dan perempuan. Hal ini berbeda dengan penelitian yang dilakukan oleh Cheung dan Cheung (2010) yang menyebutkan terdapat perbedaan kontrol diri antara laki-laki dan perempuan. Dalam penelitian tersebut, perempuan memiliki kemampuan kontrol diri yang lebih baik bila dibandingkan dengan laki-laki. Kepemilikan uang saku dan asal daerah juga tidak memiliki perbedaan yang signifikan bila dibandingkan dengan kontrol diri.

Hasil yang berbeda ditunjukkan oleh perbandingan antara klaster fakultas dengan kemampuan kontrol diri. Hasil analisis menunjukkkan terdapat perbedaan yang signifikan antara klaster vokasi dengan klaster saintek dan soshum. Klaster vokasi memiliki kemampuan kontrol diri yang lebih baik bila dibandingkan dengan klaster saintek dan soshum. Klaster agro dan klaster medika tidak memiliki perbedaan yang signifikan dengan klaster yang lain. Analisis tambahan berdasarkan perbedaan klaster peneliti lakukan berdasarkan asumsi bahwa mahasiswa yang berasal dari klaster yang sama hampir memiliki kesamaan perilaku, namun berbeda dengan klaster lainnya.

\section{Kesimpulan}

Penelitian ini dilakukan untuk mengetahui seberapa besar peran kontrol diri terhadap pembelian impulsif. Subjek penelitian merupakan mahasiswa-mahasiswi Universitas Gadjah Mada angkatan 2016. Hasil dan analisis di dalam penelitian ini berhasil membuktikan hipotesis penelitian. Hipotesis penelitian dapat diterima, yaitu terdapat peran negatif kontrol diri terhadap pembelian impulsif pada remaja akhir. Semakin tinggi kemampuan kontrol diri seseorang, maka kecenderungan pembelian impulsif akan semakin rendah dan sebaliknya, bila kemampuan kontrol diri seseorang rendah maka kecenderungan pembelian impulsif akan semakin tinggi

\section{Saran}

Hasil dalam penelitian ini menunjukkan bahwa terdapat peran negatif kontrol diri terhadap pembelian impulsif pada remaja akhir. Saran yang dapat diberikan dari penelitian ini kepada mahasiswa adalah untuk meningkatkan kontrol diri agar dapat menghindari pembelian impulsif. Saran juga dapat diberikan kepada lembaga pengembangan karakter mahasiswa, yaitu untuk memberikan intervensi kepada mahasiswa melalui komunitas untuk menghindari perilaku pembelian secara impulsif. Salah satu cara adalah dengan pemberian pelatihan kontrol diri. Penelitian ini menunjukkan terdapat $71,5 \%$ faktor lain yang menunjukkan masih terdapat faktor-faktor lain yang memberikan peran kepada seseorang dalam melakukan pembelian impulsif. Peneliti selanjutnya dapat meneliti faktor lain yang memberikan peran kepada pembelian impulsif, seperti kepribadian atau karakteristik toko.

\section{Daftar Pustaka}

Asch, S. E. (1955). Opinions and social pressure. Scientific American, 193(5), 31-35. doi: 10.1038/scientificamerican 1155-31

Baumeister, R. F., Sparks, E. A., Stillman, T. F., \& Vohs, K. D. (2008). Free will in consumer behavior: Self-control, ego depletion, and choice. Journal of Consumer Psychology, 18, 4-13. doi: 10.1016/j.jcps.2007.10.002

Burkley, E. (2008). The role of self-control in resistance to persuasion. Personality 
and Social Psychology Bulletin, 34(3), 419-431. doi: $\underline{10.1177 / 0146167207310}$ $\underline{458}$

Cheung, N. W., \& Cheung, Y. W. (2010). Strain, self-control, and gender differences in deliquency among chinese adolescents extending general strain theory. Sociological Perspectives, 53(3), 321-345. doi: 10.1177/1043986 218761932

Coley, A., \& Burgess, B. (2003). Gender differences in cognitive and affective impulse buying. Journal of Fashion Marketing and Management: An International Journal, 7(3), 282-295. doi: 10.1108/13612020310484834

Engel, J. F., Kollat, D. T., \& Blackwell, R. D. (1973). Consumer behavior 2nd edition. New York: Holt, Rinehart, and Winston.

Gailliot, M. T., Baumeister, R. F., DeWall, C. N., Maner, J. K., Plant, E. A., Tice, D. M., \& Brewer, L. E. (2007). Selfcontrol relies on glucose as a limited energy source: Willpower is more than a metaphor. Journal of Personality and Social Psychology, 92(2), 325-336. doi: 10.1037/0022-3514.92.2.325

Hurlock, E. B. (1997). Psikologi perkembangan: Suatu pendekatan rentang kehidupan. Jakarta: Erlangga.

Kasumaningrum, Y. (2015, Agustus 8). Masyarakat Indonesia kian konsumtif. Diambil kembali dari Pikiran Rakyat: http://www.pikiranrakyat.com/ekonomi/2015/08/08/33750 8/masyarakat-indonesia-kiankonsumtif

Lee, J. A., \& Kacen, J. J. (2008). Cultural influences on consumer satisfaction with impulse and planned purchase decisions. Journal of Business Research, 61, 265-272. doi: 10.1016/j.jbusres. 2007.06.006

Loudon, D. L., \& Bitta, A. J. (1984). Consumer behavior: Concepts and applications. The University of Wisconsin-Madison:McGraw-Hill.

Muratore, I. (2016). Teens as impulsive buyers: What is the role of price? International Journal of Retail $\mathcal{E}$ Distribution Management, 44(11), 11661180. doi: 10.1108/IJRDM-08-2015-0120

Primadhyta, S. (2015, 11 02). Berita bisnis: Generasi millenial RI paling impulsif belanja barang mewah. Diambil kembali dari CNN Indonesia:

http://www.cnnindonesia.com/ekono mi/20151102182452-92-88999/generasimillenial-ri-paling-impulsif-belanjabarang-mewah/

Roberts, J. A., \& Manolis, C. (2012). Cooking up a recipe for self-control: The three ingredients of self-control and its impact on impulse buying. Journal of Marketing Theory and Practice, 20(2), 173-188. doi: 10.2753/MTP1069$\underline{6679200204}$

Rook, D. W. (1987). The buying impulse. Journal of Consumer Research, 189-199. doi: $10.1086 / 209105$

Rook, D. W., \& Hoch, S. J. (1985). Consuming impulses. Advances in Consumer Research, 12, 23-27. doi: 10.5539/ijms.v5n3p149

Santrock, J. W. (2012). Adolescence. New York: McGraw-Hill.

Silvera, D. H., Lavack, A. M., \& Kropp, F. (2008). Impulse buying: The role of affect, social influence, and subjective well-being. Journal of Consumer Marketing, 25, 23-33. doi: 10.1108/ 07363760810845381

Stern, H. (1962). The significance of impulse buying today. Journal of Marketing, 26, 59-62.

Sultan, A. J., Joireman, J., \& Sprott, D. E. (2012). Building consumer self-control: The effect of self-control excercies on impulse buying urges. Mark Lett, 23, 61-72. doi: 10.1007/s11002-011-9135-4 
Tangney, J. P., Baumeister, R. F., \& Boone, A. L. (2004). High self-control predicts good adjustment, less pathology, better grades, and interpersonal succes. Journal of Personality, 72(2), 271-324. doi: 10.1111/j.0022-3506. 2004.00263.x
Verplanken, B., \& Herabadi, A. G. (2001). Individual differences in impulse buying tendency: Feeling and no thinking. European Journal of Personality, 15, 71-83. doi: 10.1002/ per. 423 